\title{
Korea invites West to help it narrow the gap in technology
}

year offering to join Japan's Intelligent Manufacturing System (IMS) project, an international project to develop computerized manufacturing systems (see below), one of the targets of G-7. Although Japan is eager to enlist the United States, Europe, Canada, Australia and the nations of the European Free Trade Association, South Korea and other newly industrialized nations have been given the cold shoulder.

The only country showing a keen interasking Western and Japanese scientists to help its companies and government research laboratories to catch up with some of the most advanced technologies of the developed world. But Western governments and Japan see little advantage for their scientists in participation, and Korea is now turning to the former Soviet Union for help.

The Highly Advanced National Project, more popularly known as the G-7 project, is intended to put Korea on a par with the G-7 nations (Japan, United States, Canada, France, Italy, Germany and the United Kingdom) by 2000 (see Nature 354, 176; 1991). About 120,000 million won (US $\$ 160$ million) has been set aside by the South Korean government in the current fiscal year, and the total proposed government investment by 2001 exceeds US $\$ 3,000$ million with a matching commitment from Korean industry (see Nature 355, 193; 1992). The first projects, to be announced next month, will cover technologies that range from semiconductors and high-definition television to biotechnology and pharmaceuticals.

South Korea's minister of science and technology, Kim Jin Hyun, hopes that by the end of this decade 20 per cent of the funds for the project will go to joint international research. His aim is to turn South Korea into the Switzerland of Asia, with international research teams of many nationalities working in Korea's institutes.

But he says the project's aims have been "misunderstood" by some advanced nations, in particular Japan. The goal is not to catch up with all of the technologies of the advanced world. Rather, South Korea wants to establish a niche in certain technologies so that the nation can survive "between the huge cheap labour market of China, with 1.2 billion people, and Japan, with its highly advanced technology".

The South Korean economy has slowed in recent years following decades of rapid growth. Democratic reforms in the political system have led to increased labour costs, while South Korea's comparatively weak protection of intellectual property rights has made advanced nations wary about licensing technology to South Korea. These factors have driven South Korea's trade balance into deficit after years of surplus, and the government sees development of indigenous high technology as the only solution.

Seven important near-market technologies - semiconductors, high-definition television, integrated services and data networks, electrical vehicles, intelligent computers, pharmaceuticals and computerized manufacturing systems - are targeted in the

G-7 project. In addition, seven areas of more fundamental research will be supported, including biotechnology, new materials and the development of environment-friendly technology.

The South Korean government is seeking the cooperation of scientists in advanced nations. A $\$ 15$ million loan from the World Bank will enable it to hire foreign experts as project advisers, says an official at the Korea Institute of Science and Technology (KIST). Government officials also hope that scientists of advanced nations will join some of the research projects. But Western government officials question whether Korea has enough to offer in return for such help.

Many of the areas identified in the programme, such as high-definition television and biotechnology, are "minefields" of problems in intellectual property rights, says one Western science officer in Seoul. Although South Korea has recently reached agreements with the United States and the European Communities over some issues involving intellectual property rights, Korea has yet to demonstrate whether the agreements will work. Korean officials play down the problem, with Chong-Won Lee, assistant minister of science and technology, saying that there is "no reason to worry about intellectual property rights".

South Koreans are particularly riled by Japan's unwillingness to collaborate. Kim and other South Korean government officials approached the Japanese Ministry of International Trade and Industry (MITI) last est in participation in the G-7 project is the former Soviet Union. The Commonwealth of Independent States (CIS) will send about 70 researchers to KIST this year for stays of a few months, and about 40 will participate in the G-7 project. The CIS researchers will collaborate on research in materials, precision engineering, material processing and aerospace technology, Lee says.

Science officers at Western embassies in Seoul say it is too early to say whether European or US researchers will participate. However, South Korea's top scientists have strong informal links with US universities and industry based on their training in the United States, and there is a large community of Korean scientists and engineers working there. Kim has also described the project to D. Allan Bromley, science adviser to President George Bush.

Within Korea, some 30 government research laboratories at institutes and universities that have recently been designated as centres of excellence will be involved in the G-7 project, as well the newly established Korea Academy of Industrial Technology. But while a few of these new research organizations have excellent facilities and staff with international connections, others do not. And observers are sceptical that Korea has sufficient talent and top-flight facilities to carry out the ambitious goals of the project.

David Swinbanks

\section{Automated factories ahead}

Tokyo. After years of delay, the Intelligent Manufacturing System (IMS) project, an international effort proposed by Japan to develop the automated factories of the future, is beginning to move forward.

Following an agreement in February between the United States, Canada, Europe, Australia and Japan at a meeting in Toronto (see Nature 355, 755; 1992), an IMS technical committee of industrialists and academics from these nations and regions met in Tokyo last month to initiate a two-year feasibility study. Six research themes were selected: enterprise integration, global manufacturing, system component technologies, clean manufacturing, human and organizational aspects and advanced materials processing.

In the next few weeks, companies and academics in each of the regions will indicate which research themes they are interested in, and in early July the committee will meet in Stuttgart, Germany, to select three or four more-precisely defined research topics. Then international research consortia will be eligible to participate in the first IMS pilot projects, which should be selected by the end of the year, according to Yuki Furukawa of the IMS technical committee.

Some newly industrialized nations have been denied a chance to participate in the feasibility study (see above). Their status will be discussed by the international steering committee of IMS at its meeting in Finland in July, Furukawa says. 